\title{
Intercultural education in the Czech Republic in the work of social educationalists Přremysl Pitter and Miroslav Dědič
}

Streszczenie: Autorzy artykułu przedstawiają wyniki badania opinii czeskich studentów na temat znaczenia filozofii czeskich pedagogów społecznych i andragogów dla ich przyszłej pracy zawodowej. Wskazują na to, że w dziedzinie edukacji międzykulturowej w Czechach wyróżniały się dwie osobistości: Přemysl Pitter (1895-1976) i Miroslav Dědič (1925). Přemysl Pitter koncentrował się na edukacji dzieci czeskich, żydowskich i niemieckich, Miroslav Dědič na edukacji dzieci czeskich, niemieckich, słowackich, a zwłaszcza romskich. Badania pokazują dość pozytywny związek studentów z wielokulturowym wymiarem filozofii wychowania i etyki wychowania obu pedagogów w stosunku do dzieci różnych narodowości. Autorzy postulują rozwój edukacji międzykulturowej zarówno w Czechach, jak i w Europie i na świecie w oparciu o myśli pedagogów nie tylko tych przywoływanych w tekście, ale i innych, np. Janusza Korczaka.

Słowa kluczowe: historie życia pedagogów, edukacja międzykulturowa, czescy pedagodzy społeczni, Přemysl Pitter, Miroslav Dědič

\section{Introduction}

In teaching social pedagogy and andragogy at Czech universities, in my opinion, the theory prevails over the attempt to historically capture the professional CVs of those personalities who, in a particular practice, sought to implement intercultural education in relation to pupils of other nationalities. Přemysl Pitter and Miroslav Dědič are such prominent personalities in the Czech Republic that need to be presented not only superficially but also in depth to students. We are trying to acquaint students with them as well as with other personalities of social educators, such as the Polish teacher Janusz Korczak, at Tomas Bata University in Zlín. For this purpose, in the academic year 2017/2018, we carried out quantitative research among students, the aim of which was to show the importance of deeply acquainting with the 
stories of social educators and andragogues, as well as the future practice of professionals we currently teach. With this research and its results we inform the reader in our text.

\section{The research of 186 respondents and its interpretation}

The aim of the research, targetted at the group of 186 respondents in humanistic fields at the Institute of Educational Sciences of the Faculty of Humanities of Tomas Bata University in Zlín, was to find out not only knowledge about social pedagogues, but also deeper, ethical, philosophical and pedagogical attitudes of students towards to them. The research was carried out in pedagogical and andragogical subjects after getting acquainted with the work and life of both social pedagogues, which took place as part of teaching subjects in andragogy and social pedagogy. We also wanted to find out by researching how the students have advanced in the depth of life stories of social educators Miroslav Dědič and Přemysl Pitter from the almost zero initial knowledge of their personalities, found at the beginning of the course through simple questioning and little pilot research, to the ability to not only present knowledge about them, but also to use them creatively to understand their philosophy and ethics of intercultural education and their subsequent use in their own practice. The first question was aimed at clarifying study groups and grades in which students were studying in the academic year 2017/2018:

Figure 1. Please, find the group you belong to:

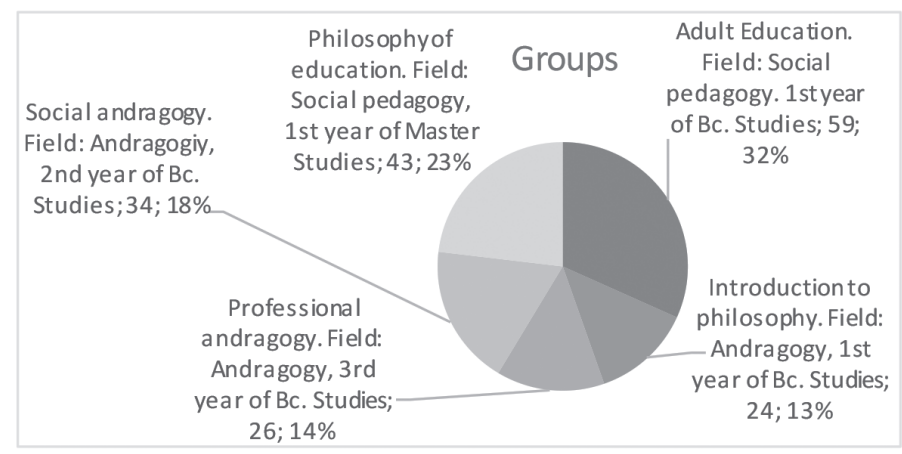

Source: Own research. 
The result of the question was to find out that the largest group was the social pedagogy of the 1st year of the bachelor's degree in the Adult Education subject, followed by a group of the first year of the master's degree in the subject of Philosophy of Education. In the field of Andragogy, there were three study groups: $2^{\text {nd }}$ year of bachelor study, subject Social andragogy, 3rd year of bachelor study, subject Professional andragogy and 1st year of andragogy, subject Introduction to philosophy. We can therefore conclude that the teaching of social pedagogues and subsequent research affected all students of the Institute of Educational Sciences at a certain stage of study, and it was very important that it was also in the first years of study, when students gain an initial attitude to study and field. Thus, a deeper understanding of the stories of social educators who were also andragogy in relation to their pupils' parents could bring the knowledge into students' minds that the study is not just about theory, but about getting to know human faces and their fates that have been linked to intercultural education of their wards, coming from different nationalities. This question was followed by another question, which followed the students' opinion on the importance of learning about the life stories of social pedagogy and andragogy professionals in relation to the theory of the field:

Figure 2. Do you agree that both theoretical knowledge and familiarization with specific life stories of personalities who have excelled in these fields are equally necessary for teaching of social pedagogy or andragogy?

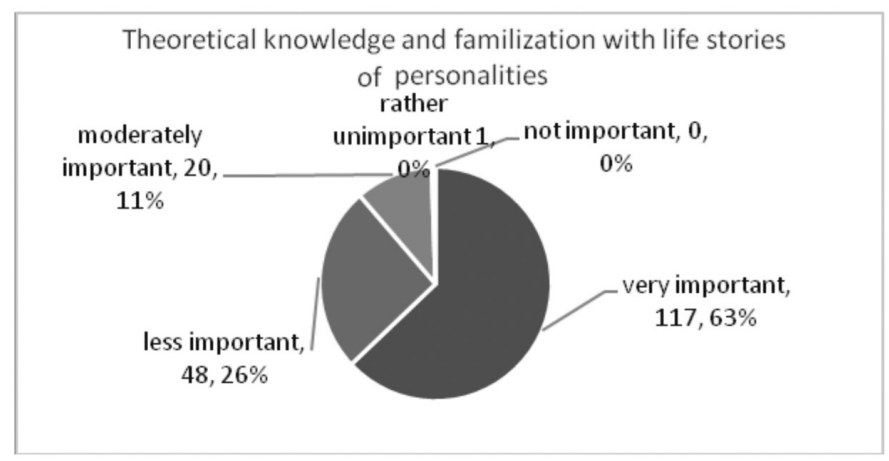

Source: Own research.

In the answers, no student has indicated that it is not important to learn the life stories of educators and andragogues. And only one of the students considers it rather unimportant. Most students consider it necessary to learn about personality stories in addition to theory (117-63\% of students). And 
others said they considered it to be moderately important (20-11\%) or less important (48-26\%). This proportion of the students' opinions gives hope that future social educators and andragogues will not merely "cram" the plain theoretical rules, but that the theory will penetrate more into their professional life through a profound understanding of the efforts and efforts of professional predecessors to achieve human and intercultural dimension in upbringing and education of future generations.

Because in many publications on pedagogy its personalities are cited in an encyclopedic way (cf. eg Cipro, 1998, 2000), or as illustrative examples for the development of theory (cf. eg Bakošová, 1994, 2006, 2011), we aimed our interpretation for students to discover a deeper, or rather deep dive, into the professional and personal life of personalities of Miroslav Dědič and Přemysl Pitter. A publication and an article by the author of this article on both personalities (Balvín, 2013, 2015) or the use of a film based on a story by Josef Pohl entitled On a Gypsy Path from 1981 (Klein, 1986; Pohl, 1981; Farkašová, 2017a, 2017b), books of social educators themselves (Dědič, 2006) and others were used for this purpose. It is an objective fact that the personality of Přemysl Pitter is recognized in a high degree in the Czech Republic and Europe. And that is why we were interested in our research how Miroslav Dědič compares do this. Therefore, we asked the following question:

Figure 3. Do you agree that in our Czech history, besides the social educator Přemysl Pitter, Miroslav Dědič also has an important place?

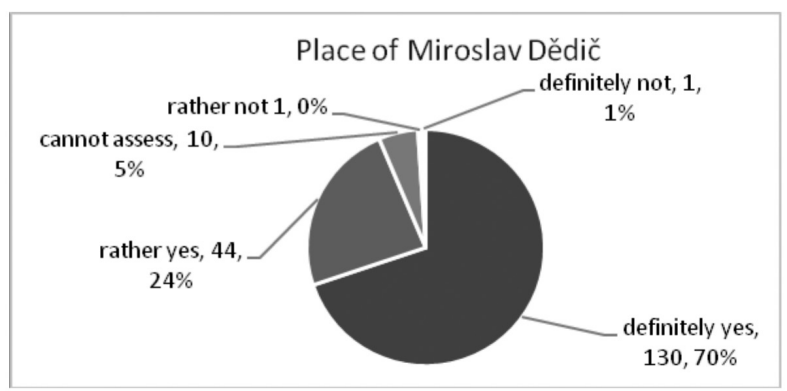

Source: Own research.

There were negative voices in the answers in only two cases. 10 (5\%) students could not assess this comparison. But 130 (70\%) students replied that Miroslav Dědič has a significant position alongside Přemysl Pitter and 44 (24\%) students said "rather yes". The communication with the students in 
the classroom as well as the research revealed that the students recognize both personalities as equal in their meaning, but evaluate differently their philosophy of interculturalism and ethics of education realized in a particular historical time, in particular conditions. That is why PŘEMYSL PITTER was called the FIRST EUROPEAN that he tried to bring up the German and Jewish children immediately after World War II TOGETHER. And on the other hand, MIROSLAV DĚDIČ excelled in his experience with German children in the border region, especially in the ROMANI CHILDREN 'S UPBRINGING in the situation, when there was no experience in the Czech Republic.

One of the main aims of teaching at universities is to prepare students as professionals who are proficient in their profession not only with knowledge but also with internal beliefs about the positive value of acquired knowledge, who are self-confident and who have gained this self-confidence by their own efforts. That is what the famous writer Umberto Eco wrote in his book How to Write a Diploma Thesis (Eco, 1977). Eco states that the one who devoted his work systematically for at least six months will become an expert in the surveyed area, and it is not right for them or anyone else to doubt it. According to him, too much modesty should not be applied here. Our next question was directed to this finding whether the students are aware that they have acquired the competence to assess the level of contribution of Přemysl Pittr and Miroslav Dědič:

Figure 4. Have you become acquainted with the life and work of these two social educators enough to gain the competence to assess the level of their contribution to Czech pedagogy and also to your own practice?

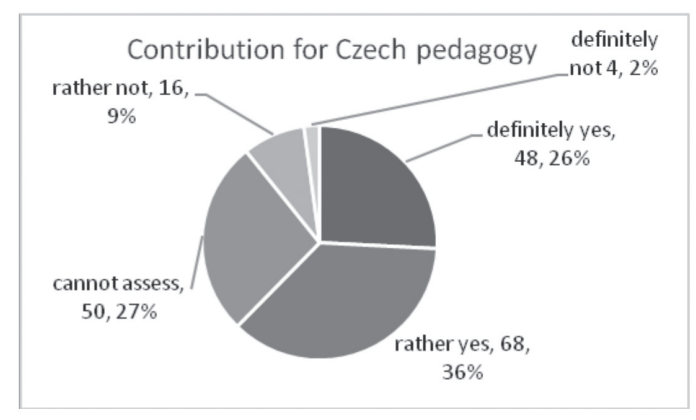

Source: Own research.

Contrary to the above-mentioned Umberto Eco about the student's selfconfidence, who was thoroughly acquainted with the question in the research, the students seemed somewhat modest in their answers. Probably because it 
was about teaching and not about creating of a thesis. 116 students (62\%) said they were so familiar with both personalities to the extent that they felt competent to assess their benefits. More modest were those who could not judge (50 students $-27 \%$ ). And even 20 students (11\%) stated that they were not able to get to know the life stories of social pedagogues enough to judge them competently. This finding points to other options that can be used in teaching. And these options include writing final, bachelor or diploma theses in which an interested student who has been interested in one of the social educators can penetrate by watching and researching their life stories, symbolically speaking, to their professional and human nature. And it is possible; this is evidenced by some diploma and bachelor thesis, published as a monograph together with the author of this essay (Balvín, Sedláček, 2016; Balvín, Smutná, 2016; Krajčovičová, Balvín, 2017; Smílková, Balvín, 2016; Smílková, Balvín, 2017; Straková, Balvín, 2019; Václavková, Balvín, 2019; Zemanová, Balvín, 2019).

In relation to the topic of the conference on multiculturalism in our country and in Europe, the question of whether the contribution of Miroslav Dědič and Přemysl Pittra has both a European and a global dimension has become an important issue. We asked students about their opinion with each social pedagogue:

Figure 5. Do you think that Miroslav Dědič's contribution also has a European and global dimension?

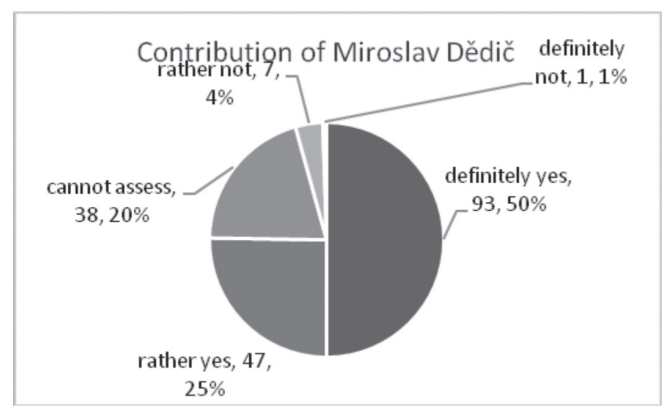

Source: Own research.

When asked about the European and world dimension of Miroslav Dědič's work, 93 students (50\%) said that Miroslav Dědič's personality certainly has this dimension and 47 students (25\%) answered "rather yes". Only 38 students (20\%) could not assess this question, and 7 students (4\%) said "rather not". And "definitely not" said one student. On the basis of this statement of students, it is 
possible to further consider the possibilities of education about the importance of Czech and European, including Polish, social pedagogues, about methods of interpretation and familiarization with the depth of their life stories. A great inspiration for us in this sense is not only the story of the Swiss social educator Pestalozzi (see Turzák, 2015), but also the story of the Polish social educator Janusz Korczak, with whom the students were acquainted mainly through the film by Wajda entitled Korczak (Wajda, 1990; Banit, 2016).

We have already pointed out the significant contribution of the personality of the social pedagogue Přemysl Pitter in relation to the personality of Miroslav Dědič. That is why we also asked a special question to assess students whether Přemysl Pitter is also of European and global importance:

Figure 6. Do you think that Přemysl Pitter's contribution also has a European and global dimension?

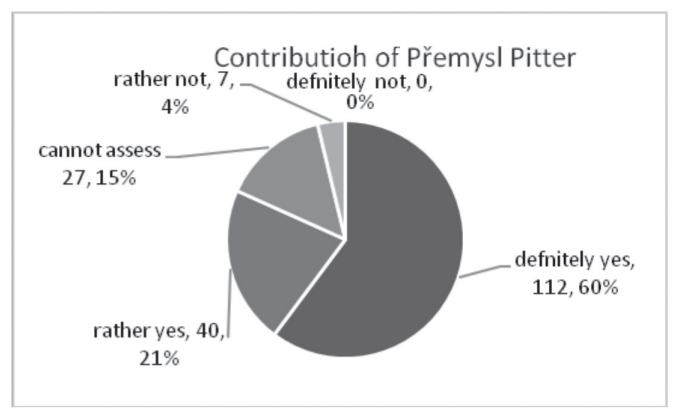

Source: Own research.

Compared to Miroslav Dědič, the question about European and world dimension was answered by students choosing "definitely yes" and "rather yes" by altogether $152(81 \%)$ and 27 students (15\%) could not assess this question. Seven students (4\%) called the option "rather not", similarly to Miroslav Dědič's case. These answers testify to the greater familiarity of the students with the life and work of Přemysl Pitter, but the difference in comparison between Pitter and Dědič is minimal. Again, it can be confirmed that the students understood the common features of both teachers and their contribution as a historical act (cf. Balvín, 2015) in specific historical conditions.

Given the topic of the conference on interculturalism in education, we were interested in whether in the common approaches to children of different nationalities, both Miroslav Dědič and Přemysl Pitter prefer interculturalism. Therefore, we asked the following question: 
Figure 7. What do pedagogues Přemysl Pitter and Miroslav Dědič have in common?

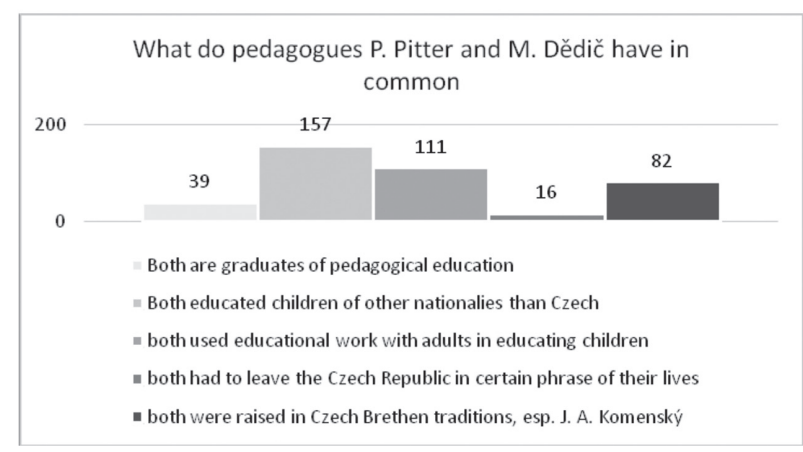

Source: Own research.

Indeed, it has turned out that the majority of students (157) assessed as the common trait that in their pedagogical work they both devoted themselves to children of other nationalities than to children of Czech nationality. It was also significant that 111 students agreed their engagement in andragogy work, and 82 students saw similarity in the fact that both Czech teachers based their education on Czech Brethren traditions, in which help to others who need it in specific conditions of history, played a very important role.

The question about the common features of both teachers was logically followed by the possibility for students to express their opinions verbally, more specifically and freely, as shown in the following table:

Table 1. Possibility to express your other opinions in words Help.

Together, they have the enthusiasm and conviction of the correctness of their thing, and this has helped them to get over the negative moments in their work.

Help.

They both acted on the basis of their heart and best consciousness.

They both tried to contribute to the education of national minorities.

Humanists, they believed in the good.

Common love for children and a desire to help them.

They dedicated their lives to helping others. They did not identify with the idea of an idle attitude.

They had an effort and helped children in a difficult period of history.

Their thoughts were based on European humanism.

They both had the courage and performed their actions selflessly.

They devoted themselves to children, both were very nice people.

Both of these important Czech personalities are an embodiment of the interest and care of children and youth regardless of religion or nationality. 


\section{Pioneers.}

Dedication, courage, willingness.

Courage and determination to do the things they did.

They both liked children.

They both liked children and dedicated them their lives.

In my opinion, both of them did a meritorious job, and if they were not there, many children of other nationalities would not have the education of such quality.

Source: Own research.

It is evident that the students accentuated the national and intercultural dimension of the work of Přemysl Pitter and Miroslav Dědič, their willingness to help children, but also their parents in difficult social situations, and the ability to respond adequately to the needs of the time the teachers and their wards lived in. In this sense, the lives and work of both personalities are comparable to the humane approach of well-known Englishman Nicholas Winton, who saved 669 Jewish children with the help of evacuation to Great Britain in former Czechoslovakia (see Balvín, 2015 and Matěj Mináčs film The Power of Humanity).

The research also included questions on the main place of work of both social pedagogues. These questions were not an end in themselves, but aimed at verifying the life stories of both social pedagogues not only in terms of geography but also in relation to the ideological, pedagogical, philosophical and pedagogical resources of their educational activities.

Question number 9 asked about place of work of social pedagogue Přemysl Pitter:

Figure 8. Do you agree that the main place of work of Přemysl Pitter was Prague?

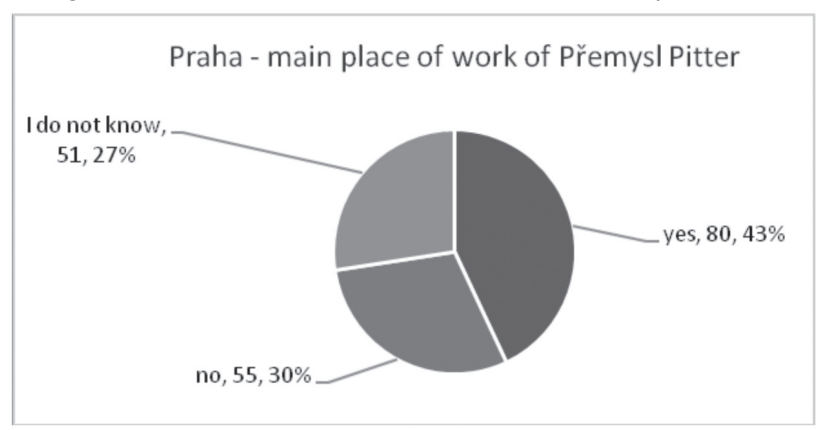

Source: Own research. 
Here, 80 (43 percent) of the students responded positively to this question, 55 (30 percent) students negatively responded and 51 (27 percent) students did not know the answer. Even this result testifies to the correct acquisition of the knowledge of the life story of Přemysl Pitter. For he, although a native of Prague who worked almost all his life in Prague, had to leave Czechoslovakia for political reasons 56 years after his birth (1895) in 1951 and live and work with his Swiss partner Olga Fierz until his death in 1976. The question about Prague is important because this capital of the then Czechoslovakia brought important ideological, educational and multicultural resources from Czech history to Pitter's life and work, and the contribution of its personalities: Jan Milíc z Kroměříže, Mistr Jan Hus, Jan Amos Komenský, Tomáš Garrique Masaryk.

In the connection with the ninth question, we asked students also about the place of work of Miroslav Dědič:

Figure 9. Do you agree that the main place of work of Miroslav Dědič was South Bohemia?

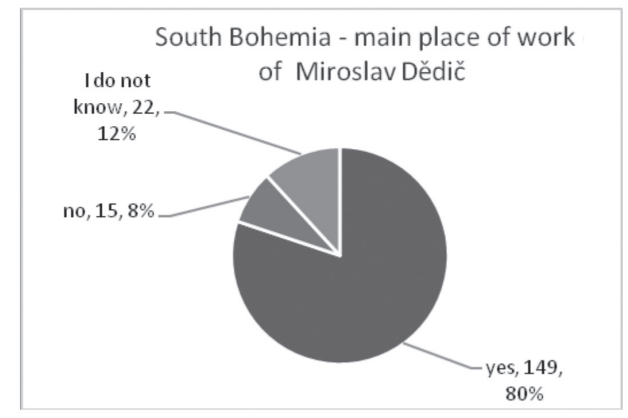

Source: Own research.

Here, the vast majority of students replied that they agreed that South Bohemia was the main place of life for Miroslav Dědič. 149 (80\%) answered the question positively, 15 (8\%) of the students answered negatively and 22 (12\%) of the respondents did not know. Also this information about social pedagogue Miroslav Dědič is significant, because - expect for the expulsion of the Czech population in 1938 from the border region after the Munich Agreement, he has lived and has been working his whole life in South Bohemia (today Chlumany $\mathrm{u}$ Vlachova Březí), where the ideas of the Church of Czech Brethren were expanded; ideas which were based in many ways on helping those who needed it at different historical times. As Dědič tells us in a film created by the author of this text together with the student of social pedagogy Martina Kastlová entitled Social Pedagogue Miroslav Dédič (Kastlová, Balvín, 2017), love your neighbor 
as yourself. And with this philosophy of education, Miroslav Dědič, in relation to pupils of other nationalities, especially in relation to Romani children, has consistently followed in his intercultural pedagogy.

\section{Conclusion}

The purpose of our text was not only to present the importance of Czech social pedagogues Přemysl Pitter and Miroslav Dědič, but also to analyze the opinions, knowledge and attitudes of students of social pedagogy and andragogy in relation to the importance of pedagogues' life stories for the study and practice of our students. The research shows quite a positive relationship of students to the application of this method in introducing the theory of the field. Students also strongly emphasized the multicultural dimension of the philosophy of education and ethics of education of both pedagogues in relation to children of different nationalities. On this multicultural aspect it is possible to further build on and develop teaching methodology both in the Czech Republic and in Europe and the world. In this respect, Polish pedagogy is particularly inspiring in the life story of Janusz Korczak for students, the specialists and us in the Czech Republic.

\section{Bibliography}

Bakošová, Z. 1994. Sociálna pedagogika. Vybrané problémy. Bratislava: Univerzita Komenského.

Bakošová, Z. 2006. Sociálna pedagogika ako životná pomoc. Bratislava: Vydavatel'stvo LORCA.

Bakošová, Z. 2011. Teórie sociálnej pedagogiky. Edukačné, sociálne a komunikačné aspekty. Bratislava: Slovenská pedagogická spoločnost’ Slovenskej akademie vied.

Balvín, J. 2011. Film jako výrazná pedagogická a andragogická metoda ve výuce. In: Sborník prací Pedagogické fakulty Masarykovy univerzity, Řada společenských věd, 25, 2011, č. 2, s. 99-104. http://ped.muni.cz/sbspolecenskevedy/sbornik/sbornik252.pdf.

Balvín, J. 2013. Přemysl Pitter: významná osobnost v historické paměti Čech a Evropy. In: Sborník prací Pedagogické fakulty Masarykovy univerzity, Řada společenských věd, roč. 27, 2013, č. 1, s. 136-141. http://www.ped. muni.cz/whis/rsv131.pdf.

Balvín, J. 2015. Sociální pedagogika a její dvě české osobnosti: Miroslav Dědič 
a Přemysl Pitter. Praha, Radix. www.jaroslavbalvin.eu. Rubrika odborná literatura.

Balvín, J. 2016a. Etika učitele jako zápas. Speciální Pedagogika, ss. 60-74. dspace.specpeda.cz/bitstream/handle/0/1603/2016_1_06.pdf?.

Balvín, J. 2016b. Filozofie, andragogika a romská kultura. Praha: Hnutí R. www.jaroslavbalvin.eu. Rubrika odborné publikace.

Balvín, J. i Farkašová, M. 2018. Social Educators and their Life Stories as Motivation to Realize their own, pedagogical professional Career. PEDAGOGIKA.SK. Slovenský časopis pre pedagogické vedy/Slovak Journal for Educational Sciences. 9, ss. 206-227.

Balvín, J. i Farkašová, M. 2018. Vzdělávání dospělých o romských komunitách s ohledem na regionální podmínky/The Education of Adults in the Topic of Romani Communities with Regard to Regional Context. In: Prusáková, V. i Matúšová, S. eds. Vzdelávanie dospelých v regionálnom kontexte. Zborník vedeckých štúdií. Vysoká škola ekonomie a manažmentu verejnej správy v Bratislave, ss. 248-266.

Balvín, J. i Sedláček, D. 2016. Sociální pedagog Anton Semjonovič Makarenko $v$ komparaci s K. D. Ušinským a V. A. Suchomlinským. Praha: Hnutí R.

Balvín, J. i Smutná, K. 2016. Lev Nikolajevič Tolstoj a jeho pedagogika. Praha: Hnutí R.

Banit, O. (Kijów). 24. 10. 2016. Korczak - recenzija filmu. In platformadobrychpraktyk.wid.org.pl/korczak-recenzja-filmu/.

Cipro, M. 1998. Prameny výchovy. Např́č staletími V. Praha: Vydavatel: Cipro Miroslav.

Cipro, M. 2000. Slovník pedagogů. Praha: Vydavatel: Cipro Miroslav.

Dědič, M. 2006. Květušínská poema. Praha: RomPraha.

Eco, U. 1977. Jak napsat diplomovou práci. Praha: Votobia.

Farkašová, M. 2017. Střihové zpracování filmu Kdo se bojí, utíká se zaměřením na komunikaci učitele s dospělými Romy. Praha: Hnutí R.

Farkašová, M. 2017. Střihové zpracování filmu Kdo se bojí, utíká se zaměřením na komunikaci učitele s romskými dètmi. Praha: Hnutí R.

Kastlová, M. i Balvín, J. 2017. Sociální pedagog Miroslav Dědič film - 1. díl. Kamera a střih Jan Grossmann. Praha: Hnutí R.

Klein, D. 1986. Kdo se bojí, utíká. Filmové drama. Režie Dušan Klein.

Krajčovičová, P. i Balvín, J. 2017. Zachránci dětí. Praha: Hnutí R.

Pohl, J. 1981. Na cikánské stezce. Praha: Albatros. 
Smílková, J. i Balvín, J. 2016. Jan Amos Komenský a jeho přinos filozofii výchovy a sociální pedagogice. John Amos Comenius and his Contribution to Philosophy of Education and Social Pedagogy. Praha: Hnutí R.

Smílková, J. i Balvín, J. 2017. Vztah kulturni a multikulturní andragogiky $k$ výchově a vzdèlávání dospélých - the Relationship of Cultural and Multicultural andragogy to Adult Education. Praha: Hnutí R.

Straková, R. i Balvín, J. 2019. Sociální pedagog Přemysl Pitter. Praha: Hnutí R. Turzák, T. 2015. Odkaz Jána Heinricha Pestalozziho jako úvod pre srovnanie so sociálnou pedagogikou Přemysla Pittra. In: Balvín, J. Sociální pedagogika a její dvě české osobnosti: Miroslav Dědič a Přemysl Pitter. Praha: Radix, ss. 64-70. www.jaroslavbalvin.eu. Rubrika odborná literatura. Václavková, A. i Balvín, J. 2019. Sociální pedagog Miroslav Dédič. Praha: Hnutí R.

Wajda, A. 1990. Korczak. Drama. Scénář Agnieszka Holland.

Zemanová, L. i Balvín, J. 2019. Sociální pedagog Janusz Korczak. Praha: Hnutí R.

\title{
Intercultural education in the Czech Republic in the work of social educationalists Přemysl Pitter and Miroslav Dĕdič
}

\begin{abstract}
The Czech Republic lies in the middle of Europe. This has resulted in contact with a number of neighboring countries and Czech teachers had to teach not only Czech children. In the field of intercultural education, two personalities excelled in the Czech Republic: Přemysl Pitter (1895-1976) and Miroslav Dědič (1925). Přemysl Pitter focused on Czech, Jewish and German children, Miroslav

Dědič on Czech, German, Slovak and especially Romany children. In our text we present research of Czech students' opinions on both personalities and the content and meaning of their intercultural education.
\end{abstract}

Keywords: life stories of educators, intercultural education, personalities of social pedagogy, Czech social educators, Přemysl Pitter, Miroslav Dědič

Translated by Jaroslav Balvín and Monika Farkašová 